\title{
Analisis Komparatif Konsep Pendidikan Karakter Perspektif Thomas Lickona dan al-Zarnuji serta Implikasinya terhadap Pendidikan Agama Islam.
}

\author{
Sholeh Hasan, M.Pd.I \\ Program Studi Pendidikan Agama Islam \\ Sekolah Tinggi Keguruan dan Ilmu Pendidikan (STKIP) Nurul Huda \\ Sukaraja Kec. Buay Madang Kab. OKU Timur Prov. Sumatera Selatan \\ e-mail: sholehhasan@stkipnurulhuda.ac.id
}

\begin{abstract}
Abstrak
Karakter dan prilaku manusia merupakan sesuatu yang dinamis. Hal yang dapat berubah setiap saat, pada kondisi dan kesempatan apapun. Ketika prilaku itu demikian sering dilakukan, ia akan manjadi bagian dari kepribadian seseorang. Proses ini disamping memerlukan pembiasaan, pada saat yang sama memerlukan legitimasi pemikiran logis. Perubahan inilah yang menyebabkan manusia mengalami degradasi status secara drastis. Tantangan paling berat dalam hal ini adalah persoalan pilihan nilai moral, budaya, dan keagamaan, terutama bagi kalangan remaja.

Dengan menggunakan metode deskriptif kualitatif dengan jenis penelitian Library Research (kajian pustaka) penulis meneliti konsep-konsep tentang pendidikan karakter yang dikemukakan Thomas Lickona dan al-Zarnuji dalam dunia Pendidikan. Sumber data diperoleh dari beberapa karya ilmiah Thomas Lickona dan al-Zarnuji sebagai data primer dan didukung dengan data sekunder lainnya.

Dari beberapa definisi pendidikan karakter, prinsip-prinsip, tujuan, fungsi dan metode dalam penerapan pendidikan karakter menunjukkan beberapa persamaan dan perbedaan. Secara definitif Lickona mengupas tuntas pendidikan karakter yang mengarah pada kesimpulan Pendidikan karakter bukan sekadar memiliki dimensi interaktif, dalam arti, mengukuhkan moral intelektual peserta didik sehingga menjadi pribadi yang kokoh tahan uji, melainkan juga harus sinergis secara personal maupun sosial. Sedang al-Zarnuji lebih mengerah pada konsep pendidikan akhlak yang diajarkan dalam Islam.

Perbedaan terdapat pada prinsip, tujuan dan metode penerapan. Hal ini dikarenakan latar belakang sosiologis, religius dan periode kehidupan keduanya yang berbeda. Tujuan pendidikan karakter bagi Thomas Lickona lebih diorientasikan pada kebaikan sosial, sedang al-Zarnuji mengarah pada dimensi sosial dan spiritual. Artinya pendidikan karakter diharapkan mampu mensinergikan antara hubungan vertikal dengan Tuhan, horisontal dengan sesama manusia dan internal terhadap personal peserta didik.

Hal ini kemudian yang peneliti implikasikan dalam dunia Pendidikan Agama Islam, diantaranya guru harus mampu menumbuhkembangkan budaya-budaya sebagai berikut: 1). Budaya berdoa dan menanamkan niat yang baik. 2) Budaya menghormati orang tua. 3) Budaya menghormati guru atau pendidik. 4) Budaya menghormati ilmu. 5). Budaya mengasihi sesama. 6) Budaya menyesal setelah berbuat salah.
\end{abstract}

Kata Kunci: Pendidikan karakter, Thomas Lickona, al-Zarnuji.

\section{Pendahuluan}

\section{Latar Belakang}

Dalam kontek Islam persoalan pendidikan merupakan masalah manusia yang berhubungan dengan kehidupan baik duniawi maupun ukhrawi. Dewasa ini, dapat kita saksikan dalam kehidupan sehari-hari bahwa banyak orang yang kehilangan karakternya sebagaimana manusia. Mereka yang kehilangan karakternya cenderung perilakunya akan didominasi oleh nafsu dan kepentingan-kepentingan instan. Meningkatnya intensitas tawuran antarwarga, antarpelajar, serta kekerasan dalam rumah tangga hingga kekerasan terhadap anak, semakin meneguhkan bahwa ada yang tidak beres dalam karakter bangsa.

Kitab Ta'lim al-Muta'allim Tariq al-Ta'allum karya al-Zarnuji hingga saat ini masih melekat erat dalam dunia pendidikan klasik (baca: pondok pesantren), lebih 
dari itu kitab ini diterapkan sebagai asas pertama dalam menuntut ilmu sehingga lebih awal diberikan kepada siswa sebelum siswa mengenal lebih jauh tentang berbagai disiplin ilmu yang lebih banyak serta interaksi dengan pendidik dan peserta didik lainnya. Hal ini dimaksudkan agar bekal yang didapat siswa lebih siap dan matang dalam menghadapi proses pembelajaran selanjutnya.

Lebih dari 8 abad yang lalu kitab Ta'lim al-Muta'allim Tariq al-Ta'allum ditulis, namun hingga saat ini masih tetap eksis didunia pendidikan klasik, menarik tentunya untuk dikaji lebih dalam. Banyak sekali pakar-pakar pendidikan yang kemudian memiliki perhatian khusus terkait etika, salah satunya Burhanuddin alZarnuji, dengan karya monumentalnya "Ta'lim al-Muta'alim Tariq al-Ta'allum".

Hal tersebut disikapi positif oleh para pemikir muslim dan Barat. Karyanya menjadi bahan referensi di berbagai penelitian, terlebih dalam dunia pendidikan. Sebut saja G. E. Von Grunebaum, salah satu ilmuan Barat yang kagum dengan pemikiran yang dituangkan oleh Burhanuddin al-Zarnuji dalam kitabnya Ta'lim alMuta'allim Tariq al-Ta'allum. ${ }^{\text {I }}$

Jauh setelah Ta'lim al-Muta'allim Tariq al-Ta'allum lahir, era 90-an muncul buku Educating For Character: How Our Schools Can Teach Respect and Responsibility karya Thomas Lickona mengguncang dunia pendidikan Barat dan menyadarkan akan pentingnya pendidikan karakter. Seorang Profesor psikologi Sidney Callahan, Ph.D, penulis buku In Good Conscience: Reason and Emotion in Moral Decision making berpendapat: Thomas Lickona telah mencetak prestasi langka yang mengkombinasikan pengetahuan yang baik dengan aplikasi yang praktis dan sangat membantu. Para guru dan orang tua akan merasakan manfaat dari karya Thomas Lickona. $^{2}$

Antara al-Zarnuji dan Lickona tentu mempunyai banyak perbedaan baik dari segi sosiologis, historis maupun religi. Pendidikan akhlak yang dibahasakan oleh alZarnuji terkesan ketimuran dan Islami sedangkan pendidikan karakter yang diangkat oleh Lickona terkesan Barat dan sekuler. Perlu diketahui bahwa, Lickona sebagai Bapak Pendidikan Karakter di Amerika justru mengisyaratkan keterkaitan erat antara karakter dengan spiritualitas. Dengan demikian, bila sejauh ini pendidikan karakter telah berhasil dirumuskan oleh para penggiatnya sampai pada tahapan yang sangat operasional meliputi metode, strategi, dan teknik, sedangkan pendidikan akhlak sarat dengan informasi kriteria ideal dan sumber karakter baik, maka memadukan keduanya bagi peneliti menjadi suatu tawaran yang sangat menarik.

Berangkat dari uraian di atas, maka dalam penelitian ini peneliti mengambil judul "Analisis Komparatif Konsep Pendidikan Karakter Perspektif Thomas Lickona dan Al-Zarnuji serta Implikasinya terhadap Pendidikan Agama Islam".

Pemilihan judul tersebut diharapkan nantinya mampu memberikan kontribusi progresif dan implikatif yang selanjutnya dapat memberikan motifasi bagi para ilmuan untuk meneliti pendidikan lainnya.

\section{Rumusan Masalah}

Beberapa permasalah dapat peneliti rumuskan sebagai berikut:

a. Bagaimana konsep pendidikan karakter menurut Thomas Lickona?

\footnotetext{
1 Abuddin Nata, Pemikiran Para Tokoh Pendidikan Islam Seri Kajian Filsafat Pendididikan Islam (Jakarta: Raja Garfindo Persada, 2003), hlm. 105

2 Thomas Lickona, Educating for Character: Mendidik untuk Membentuk Karakter, (Jakarta: Bumi Aksara, 2012), hlm.i
} 

b. Bagaimana konsep pendidikan karakter menurut al-Zarnuji?
c. Bagaimana persamaan dan perbedaan antara konsep pendidikan menurut keduanya?
d. Bagaimana implikasi pendidikan karekter dalam dunia pendidikan agama Islam?

\section{Tujuan Penelitian}

Penulisan penelitian ini didasarkan pada suatu metode penelitian yang memiliki tujuan sebagai berikut:

1. Untuk mengetahui konsep pendidikan karakter menurut Thomas Lickona.

2. Untuk mengetahui konsep pendidikan karakter menurut al-Zarnuji.

3. Untuk mengetahui persamaan dan perbedaan antara konsep pendidikan karakter menurut masing-masing penggiatnya.

4. Untuk mengetahui implikasi pendidikan karekter dalam dunia pendidikan agama Islam.

\section{Manfaat Penelitian}

\section{a. Manfaat Teoritis}

Dengan penelitian ini secara teoritis kontribusi yang diharapkan yaitu:

1) Ditemukannya konsep-konsep faktual yang komprehensif sehingga mampu menjawab persoalan-persoalan pendidikan.

2) Sebagai bahan referensi bagi penelitian yang akan datang dan yang lebih penting dijadikan sebagai pertimbangan bagi pengembangan pendidikan karakter dalam Pendidikan Agama Islam khususnya menyangkut materi moral.

\section{b. Manfaat Praktis}

1) Sebagai media pengembangan ilmu bagi peneliti atas ilmu pengetahuan yang telah diperoleh selama menempuh masa studi dan juga sebagai informasi bagi peneliti yang ingin mengkaji lebih lanjut tentang konsep pendidikan karakter dan sebagai sumber informasi bagi para pemerhati pendidikan agama Islam.

2) Untuk menambah pengalaman dan wawasan baru sebagai wadah dan wahana pengembangan pengetahuan dan cakrawala berfikir, khususnya dalam bidang pendidikan, yang selanjutnya mampu mengaplikasikan hasil positif dari penelitian sehingga dapat diharapkan apabila sudah terjun di lapangan mampu membantu guru yang erat kaitannya dengan pelaksanaan itu sendiri.

\section{Batasan Masalah}

Pada prinsipnya pembahasan terkait pendidikan karakter sudah cukup banyak diulas dalam berbagai karya ilmiah, namun menurut hemat peneliti pembahasan antara kedua tokoh ini dan mengkomparasikan belum terkupas secara eksplsit dan integratif, terlebih kedua tokoh ini orientasi pemikirannya mempunyai back ground yang berbeda. Maka dari itu, dalam penelitian ini peneliti akan memadukan dan kemudian dilakukan telaah secara intensif-integratif khusus hal-hal yang berkaitan erat dengan konsep pendidikan karakter dari hasil pemikiran Thomas Lickona dan Al-Zanuji.

\section{Penelitian Terdahulu}

1. Penelitian pernah dilakukan oleh Maftuhin (2009), mahasiswa pascasarjana jurusan Menejemen Pendidikan Islam UIN Maliki Malang dengan judul "Pengaruh Arahan Pendidikan Oleh Keluarga dan Kompetensi Guru Terhadap Pembentukan Karakter (Character Building) Siswa SMP Al-Izzah Islamic Boarding School Batu". Pada tesis tersebut mengkaji masalah pembentukan pendidikan karekter yang dilakukan oleh orang tua dan guru yang diikuti oleh 
berbagai kompetensi yang dimiliki. Temuan dalam penelitian ini menyatakan bahwa: tidak ada pengaruh positif dan signifikan arahan pendidikan oleh keluarga terhadap proses pembentukan karakter peserta didik di SMP Al-Izzah, dan terdapat pengaruh signifikan kompetensi guru terhadap proses pembentukan karakter peserta didik. ${ }^{3}$

2. Penelitian selanjutnya oleh Kristen Yuliarti (2008), Mahasiswi Pascasarjana Universitas Negeri Malang (UM) jurusan Teknologi Pendidikan dengan judul "Desain Pembelajaran Untuk Proses Pendidikan Karakter Anak (Studi Fenomenologi pada SD Kanisius Manguan Yogyakarta)". Tesis ini mengkaji beberapa proses pendidikan karakter yang ditawarkan dengan menentukan desain pembelajaran untuk proses pendidikan karakter. Dalam penelitian tersebut ditemukan bahwa pendidikan karakter di sekolah dapat dilakukan dengan dua pendekatan, yaitu secara langsung (direct) dan tidak langsung (indirect). Setrategi yang digunakan adalah peran aktif peserta didik, tidak hanya dalam kegiatan belajar di kelas, namun pada seluruh dinamika sekolahan. ${ }^{4}$

\section{Metode Penelitian}

\section{Pendekatan dan Jenis Penelitian.}

Pendekatan penelitian yang digunakan dalam penelitian ini adalah deskriptif kualitatif. Karena untuk memahami fenomena secara menyeluruh tentunya harus memahami segenap konteks dan melakukan analisa yang holistik, penjabarannya dengan dideskripsikan. ${ }^{5}$

Sedangkan jenis penelitian yang digunakan peneliti adalah Library Research (kajian pustaka). Dengan demikian, pembahasan dalam penelitian ini dilakukan berdasarkan telaah pustaka serta beberapa tulisan yang ada relevansinya dengan objek kajian.

\section{Instrumen Penelitian}

Salah satu dari sekian banyak karakteristik penelitian kualitatif adalah manusia sebagai instrumen atau alat. Moleong menyatakan bahwa kedudukan peneliti dalam penelitian kualitatif cukup rumit, ia sekaligus merupakan perencana, pelaksana, pelaksana pengumpul data, analis, penafsir data dan pada akhirnya ia menjadi pelapor hasil penelitiannya. $^{6}$

Imron Arifin mengatakan bahwa manusia sabagai instrumen berarti peneliti merupakan instrumen kunci (key instrument) guna menangkap makna. Interaksi nilai dan nilai lokal yang berbeda. Di mana hal ini tidak mungkin diungkapkan dengan kuesioner. Namun demikian instrumen penelitian kualitatif selain manusia dapat pula digunakan, tetapi fungsinya hanya terbatas sebagai pendukung tugas peneliti instrumen. ${ }^{7}$

Untuk itu dalam penelitian ini peneliti bertindak sebagai perencana, pelaksana, pelaksana pengumpul data, penafsir data yang terdapat dalam kitab.

\footnotetext{
${ }^{3}$ Maftuhin, Pengaruh Arahan Pendidikan Oleh Keluarga dan Kompetensi Guru Terhadap Pembentukan Karakter (Character Building) Siswa SMP Al-Izzah Islamic Boarding School Batu. Tesis, (Malang: Universitas Islam Negeri (UIN) Maulana Malik Ibrahim Malang, 2009)

${ }^{4}$ Kristen Yuliarti, Desan Pembelajaran Untuk Proses Pendidikan Karakter Anak (Studi Fenomenologi pada SD Kanisius Manguan Yogyakarta). Tesis, (Malang, Universitas Negeri Malang (UM), 2008)

${ }_{5}^{5}$ Sanapiah Faisal, Metode Penelitian Kualitatif (Surabaya: Usaha nasional, 1990) hlm.19.

${ }^{6}$ Lexy J Moleong, Metodologi Penelitian Kualitatif (Bandung: PT. Remaja Rosdakarya, 2002), hlm. 14

7 Imron Arifin, Penelitian Kualitatif dalam Ilmu-Ilmu Sosial dan Keagamaan (Malang: Kalimashada, 1996), hlm. 42
} 


\section{Sumber Data}

a. Data Primer, merupakan data atau karya ilmiah hasil karya Thomas Lickona dan AlZarnuji.

b. Data Sekunder, yaitu data-data yang berbentuk buku-buku, majalah, jurnal, koran, maupun artikel yang ada, dan sumber-sumber lain yang berkaitan dengan pendidikan karakter yang didapat dari selain kedua tokoh tersebut.

\section{Teknik Pengumpulan Data}

Dalam pengumpulan data peneliti menggunakan teknik dokumentasi, artinya data dikumpulkan dari dokumen-dokumen, baik yang berbentuk buku, jurnal, majalah, artikel, maupun karya ilmiah lainnya yang berkaitan dengan judul yang diangkat oleh peneliti, yakni tentang pendidikan karakter.

\section{Analisis Data}

Teknik analisis pada tahap ini merupakan pengembangan dari metode analitis kritis. Adapun teknik analisis dari penulisan ini adalah:

a. Content Analysis atau analisis isi, yakni pengolahan data dengan cara pemilahan tersendiri berkaitan dengan pembahasan dari beberapa gagasan atau pemikiran para tokoh pendidikan yang kemudian dideskripsikan, dibahas dan disimpulkan.

b. Pendekatan Hermeneutik, dalam penelitian berkaitan erat dengan pengertian data yang bersifat tekstual. Zygmut Bauman (dalam Fauzi Fashri, 2007: 19), mengatakan bahwa pendekatan hermeneutika dapat diartikan sebagai analisis dan praktik penafsiran teks. Hermeneutik dapat disederhanakan sebagai teori analisis dan praktik penafsiran bahasa, teks, gambar, pikiran, konsep dan ide-ide untuk mengungkap makna yang dipresentasikan dan menitik beratkan kebenaran rasionalitas ilmiah. ${ }^{8}$

c. Metode Komparasi, yaitu suatu metode yang digunakan untuk membandingkan data-data yang ditarik ke dalam konklusi baru. Komparasi sendiri berasal dari bahasa Inggris, yaitu compare, yang artinya membandingkan untuk menemukan persamaan dari dua konsep atau lebih. Dengan metode ini, peneliti bermaksud untuk menarik sebuah konklusi dengan cara membandingkan ide-ide, pendapatpendapat dan pengertian agar mengetahui persamaan dari ide dan perbedaan dari ide Thomas Lickona dan Al-Zarnuji. Menurut Winarno Surahmad, bahwa metode komparatif adalah suatu penyelidikan yang dapat dilaksanakan dengan meneliti hubungan lebih dari satu fenomena yang sejenis dengan menunjukkan unsur-unsur persamaan dan unsur perbedaan. ${ }^{9}$ Dalam konteks ini peneliti banyak melakukan studi perbandingan antara pandangan dari keduan tokoh yang peneliti angkat di atas.

\section{Pembahasan}

\section{A. Profil Thomas Lickona dan Al-Zarnuji}

\section{Thomas Lickona}

Dr Thomas Lickona, adalah seorang psikolog perkembangan dan profesor pendidikan di Universitas Negara Bagian New York di Cortland. Dia saat ini mengarahkan Pusat untuk Rs Keempat dan Kelima (Respect and

\footnotetext{
${ }^{8}$ Fauzi Fahri, Penyingkapan Kuasa Simbol, (Yogyakarta: Juxtapose, 2007). hlm. 19

${ }^{9}$ Winarno Surahmad, Dasar dan Teknik Penelitian, (Bandung: Trasito, 1994) hlm. 105.
} 
Responsibility) dan berada di dewan direksi dari Kemitraan Pendidikan Karakter. ${ }^{10}$

Dr. Thomas Lickona sering menjadi konsultan di sekolah-sekolah mengenai pendidikan karakter dan menjadi pembicara di berbagai seminar untuk para pendidik, orang tua, pendidik agama, dan kelompok yang peduli akan perkembangan moral kaum muda. Ia mengajar nilai moral baik di sekolah maupun di rumah mulai dari Amerika Serikat, Kanada, jepang, Singapura, Swis, Irlandia, dan Amerika Latin.

Thomas Lickona memperoleh gelar Ph.D dalam bidang psikologi dari State University of New York, Albany dengan risetnya mengenai perkembangan penalaran moral anak-anak. Ia dianugrahi State University of NewYork Faculty Exchange Scholar dan menerima penghargaan alumni kehormatan, Distinguished Alumni Award dari State university of new York di Albany. ${ }^{11}$

\section{2. al-Zarnuji}

Pengarang kitab Ta'lim al-Muta'allim Tariq al-Ta'allum ialah al-Zarnuji, nama lengkap beliau adalah Syekh Tajuddin Nu'man bin Ibrahim bin al-Khalil Zarnuji. ${ }^{12}$ Dalam Kamus Islam terdapat dua sebutan yang ditujukan kepadanya, yakni al-Zarnuji ialah Burhanuddin al-Zarnuji, yang hidup pada abad ke-6 H/ 13-14 M dan Tajuddin al-Zarnuji, ia adalah Nu'man bin Ibrahim yang wafat pada tahun $645 \mathrm{H}^{13}$

Mengenai riwayat hidup penulis kitab Ta'lim al-Muta'allim Tariq alTa'allum ini memang terjadi ketidakjelasan, ini merupakan hal yang wajar mengingat para penulis kitab klasik zaman dulu tidak butuh popularitas dan didasarkan pada niat ibadah semata. Sehingga yang muncul kemudian kitab hasil karangannya lebih popular dari pada pengarangnya. Ini juga yang terjadi pada kitab Ta'lim al-Muta'allim Tariq al-Ta'allum. Dan beberapa kajian terhadap kitab ini, tidak dapat menunjukkan secara pasti mengenai waktu kehidupan dan karir yang dicapainya.

Al-Zarnuji adalah seorang sastrawan dari Bukhara, dan termasuk ulama yang hidup pada abad ke-7 H, atau sekitar abad ke-13 sampai $14 \mathrm{M}$, ia dapat dikenal pada tahun $593 \mathrm{H}$ dengan kitab Ta'lim al-Muta'lim Tariq al-Ta'allum. ${ }^{14}$ Kitab ini telah diberi syarah (komentar) oleh Al-'Allamah al-Jalil al-Syekh Ibrahim bin Ismail, dengan nama, al-Syarh Ta'lim al-Muta'allim Tariq alTa'allum dan oleh Syekh Yahya bin Ali bin Nashuh (1007 H/ 1598M) ahli syair Turki dan Imam Abdul Wahab al-Sya'rani ahli tasauf dan al-Qadli Zakaria alAnshari. ${ }^{15}$

\section{B. Perbandingan Konsep Pendidikan Karakter Thomas Lickona dan al-Zarnuji}

\section{Perbedaan}

10 http://www.scholastic.com/teachers/article/ect-interview-thomas-lickona-phd-talks-aboutcharacter-education diakses pada 15 Desember 2012

11 Thomas Lickona, Educating for Character: Mendidik untuk Membentuk Karakter, (Jakarta: Bumi Aksara, 2012), hlm. 597

12 Syekh Ibrahim bin Ismail, al-Syarh Ta'lim al-Muta'llim, (Indonesia: Maktabah Daar Ihya' al-Kutub al'Arabiyah, tt), hlm.1.

${ }^{13}$ Ahmad Athiyatullah, Qamus Islami, (Mesir: Maktabah Nahdlah, 1970), Jilid ke-3, hlm. 58-59.

${ }^{14}$ Ibid., hlm.58

${ }^{15}$ Mahmud Yunus, Sejarah Pendidikan Islam, (Jakarta: Hidakarya Agung, 1990), hlm. 155. 
Grand design pendidikan karakter sesungguhnya sudah terkonsep sejak dulu oleh beberapa tokoh pendidikan, sebut saja Thomas Lickona dan alZarnuji yang peneliti angkat dalam penelitian ini.

Thomas Lickona dan al-Zarnuji merupakan dua tokoh pendidikan yang sama-sama berorientasi pada pembentukan mental baik terhadap peserta didik. Namun kedua tokoh ini hidup pada abad yang berbeda, Thomas Lickona lahir jauh setelah al-Zarnuji. Tidak hanya itu, dalam segi agama Thomas Lickona dan al-Zarnuji mempunyai latar belakang yang berbeda. Hal ini yang kemudian menjadikan perbedaan paradigma berfikir dari kedua tokoh ini. Agar lebih sistematis hal ini akan peneliti uraikan dalam beberapa sub:

\section{a. Definisi Pendidikan Karakter}

Pada prinsipnya mengenai konsep pendidikan karakter yang ditawarkan Thomas Lickona dengan yang ditawarkan al-Zarnuji tidak terlalu mempunyai perbedaan yang signifikan. Bagi Thomas Lickona pendidikan karakter dipahami sebagai kondisi rohaniah yang belum selesai. Ia bisa diubah dan dikembangkan mutunya, tapi bisa pula diterlantarkan sehingga tak ada peningkatan mutu atau bahkan makin terpuruk sama sekali.

Melihat cara pandang Thomas Lickona terhadap pembentukan karakter manusia ini maka pemikirannya cenderung pada aliran empirisme yang dipelopori oleh John Lock (1632-1704).

Sedangkan karakter manusia dalam pandangan al-Zarnuji dapat terbentuk oleh faktor internal dan eksternal, artinya dalam proses perjalanannya intervensi Tuhan sebagai pencipta watak dan sikap baik maupun buruk manusia, lingkungan, disertai kerjasama dengan potensi hereditas yang nantinya akan membentuk sebuah karakter dalam diri manusia. Seseorang dapat saja dipengaruhi oleh alam lingkungannya secara penuh atau sebaliknya dunia luar yang justru dipengaruhinya sehingga sesuai dengan keinginannya. Atau dirinya dan lingkungan melebur secara timbal balik terus menerus dan saling mempengaruhi.

Dalam Ta'lim al-Muta'allim nampaknya al-Zarnuji lebih banyak menekankan kepada penataan lingkungan sosial budaya, seperti memilih pendidik, memilih teman dan memilih lingkungan tempat pembelajar menimba ilmu. Sekalipun demikian, belum dapat dikatakan bahwa alZarnuji beraliran Empirisme, karena dalam bab lain beliau juga membicarakan tentang tawakkal. Tawakkal tentu merupakan salah satu ciri dari yang beraliran Nativisme. Sehingga dalam hal ini lebih tepat kalau alZarnuji dikelompokkan pada aliran Konvergensi.

\section{b. Prinsip Pendidikan Karakter}

Konstruk pemikiran Thomas Lickona menunjukkan kepada para pendidik cara menciptakan rasa tanggung jawab dan komunitas ruang kelas yang peduli di mana pencapaian akademis dan perkembangan moral dapat tumbuh. Pendidikan karakter harus bersifat multilevel dan multi-channel karena tidak mungkin hanya dilaksanakan oleh sekolah, pembentukan karakter perlu keteladanan, perilaku nyata dalam setting kehidupan otentik dan tidak bisa dibangun secara instan. Oleh karena itu, pendidikan karakter harus menjadi sebuah gerakan moral yang bersifat holistik, melibatkan berbagai pihak dan jalur, dan berlangsung dalam setting kehidupan alamiah. 
Berbeda dengan al-Zarnuji, beliau menulis kitab Ta'lim alMuta'allim ini selain memang kondisi peserta didik pada saat itu banyak yang dirasa ilmunya tidak bermanfaat juga didasarkan pada tuntutan agama yang mengharuskan adanya pendidikan akhlak. Sebab agama Islam yang dianut oleh al-Zarnuji adalah agama akhlak, dimana Nabi Muhammad sebagai Nabi terakhir zaman diutus ke muka bumi ini memang untuk menyempurnakan akhlak yang baik. sehingga pendidikan karakter yang diusungnya berdiri di atas prinsip-prinsip agama, yaitu agama Islam. Dimana al-Qur'an dan al-Hadits sebagai pedoman dalam setiap tindakan.

\section{c. Fungsi Pendidikan Karakter}

Berangkat dari faktor latar belakang yang berbeda maka muaranya adalah orientasi pada fungsi pendidikan karakter yang berbeda pula. Thomas Lickona lebih mengarahkan fungsi sosiologis sedangkan al-Zarnuji pada wilayah religi meskipun pada akhirnya juga berdampak pada wilayah sosial.

\section{d. Tujuan Pendidikan Karakter}

Tujuan utama pendidikan karakter bagi Thomas Lickona adalah cerdas dan berperilaku baik. ${ }^{16}$ Itulah muara dari pendidikan karakter yang digadang-gadangkan Thomas Lickona. Model pendidikan karakter yang dikembangkan Thomas Lickona adalah bagaimana caranya dia menggambarkan proses perkembangan yang melibatkan pengetahuan, perasaan, dan tindakan nyata. Jadi ada semacam penyediaan fondasi secara terpadu, di mana di atasnya dapat dibangun suatu struktur yang terjalin dari berbagai upaya pendidikan karakter yang koheren dan komprehensif.

Berbeda dengan Al-Zarnuji, beliau telah memberikan solusi tentang bagaimana menciptakan pendidikan yang tidak hanya berorientasi pada duniawi belaka, tetapi juga berorientasi pada dimensi akhirat (ukhrawi). Sebagaimana tujuan sentral pendidikan menurut Al-Zarnuji adalah mencari ridha Allah SWT. serta kebahagiaan di akhirat. Yang selanjutnya disertai dengan norma-norma yang disyariatkan Allah SWT. baik kaitannya dengan hubungan vertikal, horisontan dan internal.

\section{e. Metode Pendidikan Karakter}

Thomas Lickona juga memberikan anjuran misalkan, pendidik dituntut untuk melakukan pendekatan komprehensif di dalam ruang. Melihat dari metode yang diterapkan oleh Thomas Lickona bahwa ia menempatkan peserta didik sebagai subyek aktif yang dapat melakukan proses pembelajaran dengan pendidik. Hal ini diharapkan dapat meningkatkan motivasi dan aktivitas peserta didik dalam proses pembelajaran. Bahkan dengan pembelajaran yang lebih berorientasi pada siswa aktif ini, pendidik mampu membentuk karakter pribadi dan sekaligus karakter sosial dengan meningkatkan penghayatan dan pengamalan peserta didik dalam kehidupan di kelas dan di lingkungan sosialnya.

Berbeda dengan al-Zarnuji, sebagaimana tersurat dalam teks kitab Ta'lim al-Muta'allim, posisi pendidik seakan menjadi penentu utama bagi keberlangsungan pembelajaran peserta didik terhadap masa depannya, alZarnuji mengusung sistem belajar siswa pasif, karena pendidik adalah penentu utama, semua kembali kepada pendidik. Sehingga metode yang

\footnotetext{
${ }^{16}$ Ibid., hlm.7
} 
dipakai berfokus pada buku panduan dan kegiatan belajar mengajar (KBM) satu arah, sistem pengajaran yang monologis atau lebih lazim dengan sebutan sistem tradisional.

\section{Persamaan}

Dalam pandangan peneliti, konsep yang ditawarkan oleh Thomas Lickona dan al-Zarnuji lebih banyak perbedaannya meskipun tidak signifikan menyentuh pada prinsip dari pendidikan karakter itu sendiri. Hal ini didukung oleh latar belakang sosial, budaya, dan agama yang berbeda dari kedua tokoh tersebut.

\section{a. Definisi Pendidikan Karakter}

Pada ulasan mengenai definisi pendidikan karakter yang dikonsepsikan oleh Thomas Lickona dan al-Zarnuji sesungguhnya mempunyai satu titik kesepakatan bahwa karkater merupakan suatu tabiat yang melekat pada manusia, dan manusia lahir kedunia dalam keadaan tidak mengetahui apa-apa serta tidak memiliki ilmu pengetahuan. Namun dibekali dengan indra pendengaran, penglihatan, akal dan hati yang merupakan bekal dan potensi sekaligus sarana untuk membina dan mengembangkan kepribadiannya. Secara bertahap melalui jalur pendidikan, potensi dan sarana itu dibina serta dikembangkan sehingga tercapai bentuk kepribadian yang diharapkan.

\section{b. Prinsip Pendidikan Karakter}

Menurut hemat peneliti tidak ada persamaan signifikan terkait prinsip-prinsip yang dikembangkan oleh Thomas Lickona dan al-Zarnuji dalam pendidikan karakter.

\section{c. Fungsi Pendidikan Karakter}

Persamaan dimunculkannya ide mengenai penanaman nilai-nilai karakter ini terletak pada kegelisahan yang dialami oleh kedua tokoh ini atas fenomena sosial yang berkembang pada masing-masing periodenya. Sehingga keduanya merasa terpanggil untuk segera merumuskan konsep yang diikuti dengan segala bentuk aktifitasnya.

Tanggung jawab sosial yang dirasakan oleh Thomas Lickona dan alZarnuji ini memang tidak mudah, sebab merubah sikap dan perilaku orang banyak butuh ketelatenan dan kesabaran. Sehingga karya tulis mereka tidak lain memang diproyeksikan untuk kebutuhan sosial pada masanya. Melalui ide-ide yang kemudian dituangkan dalam sebuah karya tulisnya ternyata mampu merubah sikap yang lebih bermoral hingga detik ini masih kita rasakan pengaruhnya.

\section{d. Tujuan Pendidikan Karakter}

Thomas Lickona dan al-Zarnuji mempunyai semangat dan tujuan yang sama dalam proses pembentukan karakter yang baik bagi peserta didik. Karya, perilaku dan aktivitasnya sudah cukup memberikan bukti nyata atas dedikasi yang diberikan pada dunia pendidikan supaya menghasilkan generasi-generasi muda yang memiliki mental, perilaku dan orientasi kehidupan yang lebih baik.

\section{e. Metode Pendidikan Karakter}

Dalam internalisasi nilai-nilai karakter pada peserta didik yang dilakukan Thomas Lickona dan al-Zarnuji, keduanya sama-sama memberlakukan metode diskusi (munadharah) dalam menyelesaikan suatu 
permasalahan serta metode cerita (qishah) dalam beberapa kesempatan. Efektifitas proses pendidikan karakter dipengaruhi oleh ketepatan pendekatan yang dipilih pendidik dalam mengajarkan materi tersebut. Dalam uraian bab sebelumnya Thomas Lickona dalam praktik pengajarannya cenderung menggunakan metode pembelajaran aktif dan kekinian sedang al-Zarnuji menggunakan metode pembelajaran pasif dan masih sarat dengan mitologis dan sufistik. Sehingga peserta didik lebih cenderung pasif dan kendali ada di tangan pendidik.

Pembinaan karakter sangat terkait kepada dua unsur substansial dalam diri manusia yaitu jiwa dan jasmani dengan budi pekerti yang baik, berarti juga mengisi perilaku dan tindakan mulia yang dapat dimanifestasikan oleh jasmani. Atau dengan kata lain, karakter yang terdapat di dalam jiwa turut mempengaruhi keutamaan pribadi seseorang. Oleh karena itu, karakter harus dijadikan sebagai orientasi hidup di setiap masa dan waktu

Uraian perbandingan konsep pendidikan karakter di atas peneliti gambarkan dalam bagan sebagai berikut:

Tabel 1. Perbandiangan Konsep Pendidikan Karakter Thomas Lickona dan al-Zarnuji

\begin{tabular}{|c|c|c|c|}
\hline \multirow[t]{2}{*}{ Konsep } & \multirow{2}{*}{$\begin{array}{c}\text { Persamaan } \\
\text { Thomas Lickona dan } \\
\text { Al-Zarnuji }\end{array}$} & \multicolumn{2}{|c|}{ Perbedaan } \\
\hline & & Thomas Lickona & Al-Zarnuji \\
\hline 1. Definisi & $\begin{array}{l}\text { Tabiat yang dimulai } \\
\text { dari nol dan dapat } \\
\text { diolah }\end{array}$ & Empirisme & Konvergensi \\
\hline 2. Prinsip & $\begin{array}{c}\text { Signifikansi pada } \\
\text { konteks }\end{array}$ & Konteks sosial & Religius \& Konteks \\
\hline 3. Fungsi & $\begin{array}{l}\text { Tanggung jawab } \\
\text { sosial }\end{array}$ & Sosiologis-praksis & $\begin{array}{l}\text { Religius \& } \\
\text { Sosiologis }\end{array}$ \\
\hline 4. Metode & $\begin{array}{ll}\text { - } & \text { Metode Diskusi } \\
\text { (Munadharah) } \\
\text { - } & \text { Metode } \\
& \text { Keteladanan }\end{array}$ & $\begin{array}{ll}- & \text { Metode } \\
\text { Uswah } \\
\text { - } & \text { Metode } \\
\text { Qishah } \\
\text { - } & \text { Metode Moral } \\
& \text { reasoning } \\
\text { - } & \text { Metode } \\
& \text { Belajar Aktif }\end{array}$ & $\begin{array}{ll} & \text { Metode Diskusi } \\
\text { (Munadharah) } \\
\text { - } \\
\text { Metode saling } \\
\text { mengingatkan } \\
\text { (mudzakarah) } \\
\text { Metode } \\
\text { menghafal } \\
\text { Metode Belajar } \\
\text { Pasif }\end{array}$ \\
\hline 5. Tujuan & $\begin{array}{l}\text { Orieantasi pada } \\
\text { pembentukan mental }\end{array}$ & $\begin{array}{l}\text { Orientasi pada } \\
\text { pembentukan: } \\
\text { Intellegent } \\
\text { Quotient (IQ), } \\
\text { dan Moral } \\
\text { Quotient (MQ). }\end{array}$ & $\begin{array}{l}\text { Orientasi pada } \\
\text { pembentukan: } \\
\text { Intellegent Quotient } \\
\text { (IQ), Moral Quotient } \\
\text { (MQ), Spiritual } \\
\text { Qoutient (SQ), } \\
\text { kebahagiaan dunia } \\
\text { dan akhirat }\end{array}$ \\
\hline
\end{tabular}

\section{Implikasi Pendidikan Karakter dalam Pendidikan Agama Islam}


Implikasi merupakan sebuah keterlibatan. Maka keterlibatan pendidikan karakter terhadap dunia pendidikan agama Islam adalah sebuah keniscayaan. Karena agama Islam sendiri merupakan agama yang diturunkan untuk mencetak karakter umat yang baik.

Dan yang perlu kita pahami bahwa Pendidikan Agama Islam merupakan salah satu mata pelajaran yang berada dalam kurikulum pendidikan nasional. Sementara posisi kurikulum sebagai jantungnya pendidikan, maka sudah seharusnya kurikulum saat ini memberikan perhatian lebih pada pendidikan karakter dibandingkan kurikulum sebelumnya. Pembelajaran merupakan bentuk kongkrit atau realisasi kurikulum sebagai dokumen tertulis di sekolah atau kelas, maka aktivitas pembelajaran yang relevan dilaksanakan pendidik untuk pembentukan insan berkarakter tentu tidak dapat dipisahkan dengan karakteristik kurikulum yang berlaku di sekolah.

Salah satu cara yang relevan diterapkan adalah pengintegrasian karakter atau nilai-nilai ke dalam kegiatan pembelajaran pada mata pelajaran Pendidikan Agama Islam. Meskipun dalam wilayah materi ajar Pendidikan Agama Islam sudah sarat dengan pendidikan nilai yang dalam praktik penerapannya masih banyak mengutamakan ranah kognitif.

Nilai-nilai yang perlu untuk ditanamkan tersebut diantaranya: Cinta kepada Allah SWT. dan alam semesta beserta isinya, tanggung jawab, disiplin, jujur, hormat dan santun, kasih sayang, peduli dan kerja sama, percaya diri, kreatif, kerja keras, pantang menyerah, adil, rendah hari, toleransi, dan lain sebagainya.

Namun bagi peneliti ada hal yang lebih penting lagi dari pada proses integralisasi nilai-nilai ke dalam kurikulum. Sebab menanamkan nilai hingga menjadi sebuah karakter butuh waktu dan proses yang dilakukan secara terusmenerus dan konsisten. Maka dalam hal ini perlu untuk diadakan pengembangan budaya praktis dalam mengimplementasikan nilai-nilai yang positif. Budaya-budaya itu antara lain:

1. Budaya berdoa dan menanamkan niat yang baik

Penanaman kebiasaan berdoa dalam setiap memulai aktifitas dan niat yang baik disertai dengan kesadaran akan pentingnya ilmu pengetahuan sebagai bekal hidup perlu untuk dilakukan sejak dini supaya peserta didik tahu dan sadar sehingga dalam perjalanannya nanti ia akan merasa perlu dan butuh terhadap ilmu, terlebih ilmu agama Islam.

Muatan-muatan yang perlu untuk disampaikan dan ditanamkan pada peserta didik misalnya, niat merupakan syarat sebuah amal membuahkan pahala. Amalan mubah seperti makan, minum, dan sebagainya, jika diawali dengan doa diiringi dengan niat yang benar, semisal karena memenuhi perintah Allah dan Rasul-Nya serta untuk membantu dalam melaksanakan ketaatan, maka bisa menjadi amal shalih dan pelakunya diberi pahala, terlebih jika amalan itu berupa belajar untuk menuntut ilmu.

Selain itu peserta didik hendaknya diberikan arahan untuk senantiasa membersihkan hatinya sebelum menuntut ilmu. Hal ini disebabkan karena belajar adalah ibadah dan tidak sah ibadah kecuali dengan hati yang bersih. Tujuan belajar hendaknya ditujukan untuk menghiasi ruh dengan berbagai sifat keutamaan. Hal ini yang sekarang jarang dilakukan oleh pendidik sehingga yang terjadi adalah ketidaktahuan peserta didik tentang urgensi dan hakikat dari ilmu yang ia pelajari. 
2. Budaya Menghormati Orang Tua

Sering kita saksikan di media cetak, media massa maupun media on line kasus terjadinya kekerasan anak terhadap orang tuanya. Jika dulu orang tua memarahi anaknya karena nakal itu sudah wajar, tapi sekarang justru sebaliknya dan lebih ekstrim. Anak membunuh orang tua! Subhanallah, tentu ini perbuatan yang harus kita hindari jauh-jauh sejak dini. Perlu ada tindakan nyata dan dimulai dari diri kita masing-masing dan dari profesi kita masing-masing.

Sebagai pendidik, di sekolah perlu penekanan terhadap peserta didik bahwa menghormati orang tua adalah kewajiban yang harus dilakukan setiap hari. kewajiban orang tua sama dengan pendidik, bahkan melebihi dari sekedar mendidik. Karena orang tua merupakan orang pertama yang mengenalkan anak didik tentang banyak hal sebelum pendidik. Oleh sebab itu selayaknya bagi seorang peserta didik wajib melaksanakan apa-apa yang dilakukan terhadap pendidik, juga menjadi kewajiban untuk dilakukan terhadap orang tuanya.

Birrul walidain atau berbuat baik kepada kedua orang tua adalah amal kebaikan yang sangat mulia di dalam Islam. Kedudukannya disandingkan dengan perintah tauhid (ibadah kepada Allah dan tidak menyekutukan-Nya dengan apapun juga) dalam beberapa ayat Al-Qur'an. Ini menjadi bukti kuat keagungan amal ini. Ditambah keterangan, bahwa bakti ini sebagai bentuk syukur atas jasa-jasa keduanya sejak dikandungan, bayi sehingga menjadi besar dan dewasa.

Penanaman nilai-nilai tersebut di atas harus dimulai sejak awal dan berulang, pada setiap kesempatan hingga membiasa, supaya peserta didik mempunyai bekal pengetahuan tentang kemulyaan dan terbiasa menghormati serta mengasihi kedua orang tuanya.

3. Budaya Menghormati Guru atau Pendidik

Tidak sulit juga saat ini untuk menemukan kasus peserta didik yang meremehkan terhadap pendidik. Bahkan pendidik harus acap kali menangis karena tidak mampu mengkondisikan ulah peserta didik di kelas. Jika demikian yang terjadi maka bagaiman dan dari mana ilmu yang diberikan olehnya akan terserap ke peserta didik?

Untuk itu, budaya ini bisa diciptakan oleh pendidik itu sendiri dengan perilaku dan teladan-teladan yang dicontohkan. Semisal pendidik selalu menjaga sikap dan wibawa di manapun ia berada, menghargai setiap kreasi peserta didik, menyayangi dan juga santun dalam berinteraksi dengan mereka.

Guru atau pendidik adalah orang yang mengajarkan kita dengan berbagai ilmu pengetahuan dan mendidik kita menjadi orang yang berguna pada masa akan datang. Walau bagaimana tingginya pangkat atau kedudukan seseorang itu mereka adalah bekas seorang pelajar yang tetap berhutang budi kepada gurunya yang pernah mendidiknya pada masa dahulu.

Oleh karena itu Islam mengajar kita supaya menghormati pendidik dan memuliakannya sebagaimana kita memuliakan ibu bapak kita. Kerana merekalah ilmu dapat tersampaikan kepada kita untuk kebahagiaan di dunia dan di akhirat. Guru atau pendidik adalah orang tua kedua kita selama di sekolah.

4. Budaya Menghormati Ilmu

Jika di kelas terdapat peserta didik yang enggan dan tidak mempunyai semangat untuk mengikuti semisal mata pelajaran Pendidikan Agama Islam itu dikarenakan peserta didik kurang tahu dan sadar akan pentingnya ilmu di 
kemudian hari. Maka perlu untuk didogma bahwa ilmu adalah perisai yang akan melindungi pemiliknya dari kehancuran. Bangsa yang terhormat, berjaya dan menjadi penguasa di dunia adalah bangsa yang berilmu pengetahuan.

Dalam panggung sejarah kita menyaksikan bangsa yang memiliki kekayaan alam yang berlimpah tetapi sedikit ilmu pengetahuan, terbukti kekayaannya tidak dapat menolong dan memberikan kemaslahatan, melainkan justru dapat menimbulkan konflik dan kehancuran. Sebaliknya bangsa yang berilmu pengetahuan walaupun tidak memiliki kekayaan alam terbukti dapat menciptakan kemakmuran, kesejahteraan dan kehormatan.

Islam adalah agama yang sangat menjunjung tinggi ilmu pengetahuan. Tuhan mendorong, memanggil dan memerintah agar umat Islam menuntut ilmu dan menjadi umat yang yang berilmu. Tidak hanya itu, Islam juga akan mengangkat derajad orang yang berilmu. Sebaliknya Tuhan menyindir, mengejek dan mengecam umatnya yang bodoh tidak mau belajar. Allah berjanji akan mengangkat derajat orang-orang yang beriman dan berilmu pengetahuan lebih tinggi dibanding umat atau bangsa lainnya.

Jika nilai-nilai ini sudah tertanam erat pada diri peserta didik, peneliti yakin tidak ada lagi peserta didik yang pura-pura lupa mengerjakan PR. Dan antusiasme dalam mengikuti setiap mata pelajaran akan tercipta dengan baik.

5. Budaya Mengasihi Sesama

Fenomena tawuran antarpelajar, tindakan kekerasan terhadap teman sekelas, muncul geng pada tiap kelas dan lain sebagainya merupakan fakta ketidakberhasilan penanaman nilai karakter yang baik di kalangan peserta didik. Menyinggung perasaan orang lain itu sangat mudah, mugkin kita tergolong bangsa yang emosional, tapi juga bangsa yang memiliki hasrat besar. Jika semua diarahkan ke tujuan yang baik, pasti akan menjadi bangsa yang besar.

Nilai-nilai yang perlu untuk ditanamkan secara berkesinambungan adalah: Suka menolong sesama, tidak mementingkan diri sendiri, sabar, rendah hati, toleransi dengan berbagai perbedaan dan lain sebagainya.

Awal dari rasa saling asah dan saling asuh adalah menyadari untuk mengasihi. Reaksi spontanitas yang emosional, merupakan pembelaan dari ketidaknyamanan. Kita bisa menghindar dari masalah hati ini, bila mengawali segalanya dengan niat baik, rendah hati, serius berkomitmen bukan saja di backstreet, tapi luar dan dalam. Penanaman sikap saling mengasihi, menghormati dan menyayangi sesama ini perlu dilakukan setiap saat.

6. Budaya menyesal setelah berbuat salah

Bangga setelah melakukan perbuatan yang salah sekarang sudah marak terjadi di kalangan peserta didik, tidak lagi malu atau takut dengan konsekwensi sosial yang akan dihadapi. Sudah banyak juga dicontohkan oleh publik figur dalam kasus-kasus seperti korupsi yang justru ia tersenyum manis ketika disorot kamera wartawan. Sepertinya hukuman tidak lagi memberikan efek jera bagi mereka. Sunggu ini persoalan yang serius terutama bagi guru Pendidikan Agama Islam.

Menumbuhkan rasa penyesalan setelah berbuat salah memang sangat sulit, untuk itu perlu dimulai dari keluarga dan sekolahan. Harus diberi pemahaman yang logis bahwa konskwensi dari berbuat yang negatif itu pada hakikatnya bukan sekarang, tapi besok di Hari Perhitungan (Yaum al-Qiyamah). 
Menyesal dan malu terhadap diri sendiri merupakan tingkatan akhlak yang paling tinggi. Dampak dari perbuatan tidak baik itu sesungguhnya tidak hanya bagi orang lain tapi juga diri sendiri.

Tindakan-tindakan di atas memang sudah banyak terkonsepsikan dalam wilayah teori, sehingga harus ada tindakan nyata yang dilakukan terutama oleh guru Pendidikan Agama Islam. Mengingat guru Pendidikan Agama Islam yang selama ini menjadi sorotan tajam atas terjadinya perilaku-perilaku menyimpang yang dilakukan peserta didik.

Melalui kerjasama dengan orang tua, seluruh pendidik dan tenaga kependidikan di sekolah, budaya-budaya itu ditumbuhkembangkan bersama-sama. Pembiasaan adalan sesuatu aktivitas yang sengaja dilakukan secara berulang-ulang agar sesuatu itu menjadi kebiasaan. Metode pembiasaan (habituation) ini berintikan pengalaman nyata. Karena yang dibiasakan itu adalah sesuatu yang diamalkan. Dan inti pembiasaan adalah pengulangan.

Pada saat pemahaman (moral knowing) dan kesadaran (moral feeling) sudah tercipta dengan baik lalu didukung dengan budaya implementasi nilai-nilai karakter yang baik (moral behaviour) peneliti yakin semua akan berjalan sesuai harapan kita bersama. 


\section{Penutup}

\section{A. Kesimpulan}

Dalam paradigma lama, keluarga dipandang sebagai lingkungan yang paling efektif untuk pendidikan karakter. Hal ini bisa dipahami, karena pada masa lalu, lazimnya keluarga-keluarga bisa berfungsi sebagai tempat terbaik bagi anak-anak untuk mengenal dan mempraktikkan berbagai kebajikan. Para orang tua biasanya memiliki kesempatan yang cukup serta mampu memanfaatkan tradisi yang ada untuk mengenalkan secara langsung berbagai nilai-nilai moral kepada anak-anak melalui teladan, petuah, cerita atau dongeng, dalam kebiasaan setiap hari secara intensif. Demikianlah, keluarga-keluarga pada masa lalu umumnya dapat diandalkan sebagai tulang punggung pendidikan karakter.

Akan tetapi, proses modernisasi membuat banyak keluarga mengalami perubahan yang signifikan. Atas dasar tuntutan pekerjaan, kini banyak keluarga yang hanya memiliki sangat sedikit waktu bagi berlangsungnya perjumpaan yang intim antara ayah, ibu, dan anak. Bahkan, makin banyak keluarga yang, karena tuntutan pemenuhan kebutuhan hidup, memilih untuk tidak tinggal dalam satu rumah, melainkan saling berjauhan tempat tinggal antara ayah, ibu, dan anak. Belum lagi, makin banyak keluarga bermasalah: tidak harmonis, terjadi berbagai kekerasan dalam rumah tangga, bahkan perceraian.

Singkat kata, kini makin banyak keluarga yang tidak bisa berfungsi sebagai tempat terbaik bagi anak-anak untuk mendapatkan pendidikan karakter. Itulah sebabnya amat baik bila sekolah menyelenggarakan pendidikan karakter. Bahkan, sekolah perlu terus berupaya menjadikan dirinya sebagai tempat terbaik bagi kaum muda untuk mendapatkan pendidikan karakter di usia dini.

Pada dasarnya, anak yang kualitas karakternya rendah adalah anak yang tingkat perkembangan emosi-sosialnya rendah, sehingga anak beresiko besar mengalami kesulitan dalam belajar, berinteraksi sosial, dan tidak mampu mengontrol diri. Mengingat pentingnya penanaman karakter di usia dini dan mengingat usia prasekolah merupakan masa persiapan untuk sekolah yang sesungguhnya, maka penanaman karakter yang baik di usia prasekolah merupakan hal yang sangat penting untuk dilakukan.

Bila ditilik banyak faktor yang melatarbelakangi ketidakberhasilan pendidikan karakter di sekolah misalnya kecenderungan pengenalan nilai-nilai kepada siswa, sementara tataran implementasinya diabaikan.

Untuk itulah, seperti yang sudah banyak dibahas oleh beberapa pakar pendidikan, dibutuhkan keterlibatan semua pihak mulai dari isi kurikulum, proses pembelajaran dan penilaian, penanganan atau pengelolaan mata pelajaran, pengelolaan sekolah, pelaksanaan aktivitas atau kegiatan kurikuler, pemberdayaan sarana dan prasarana, serta etos kerja seluruh warga di lingkungan sekolah.

Sesuai dengan yang diungkapkan Thomas Lickona, "Character so conceived has three interrelated parts: moral knowing, moral feeling, and moral behavior". Namun peneliti lebih menekankan dalam wilayah moral behavior. Sebab wilayah ini peneliti rasa kurang mendapatkan perhatian serius dari para penggiat pendidikan karakter. Dalam menanamkan nilai-nilai kepada siswa di sekolah, peranan pendidik sangatlah penting karena menjadi ujung tombak pembelajaran di kelas yang berhadapan langsung dengan peserta didik. Pendidik semestinya menjadi teladan, model seperti dalam filosofi jawa guru itu "digugu lan ditiru". Beberapa hal yang bisa dilakukan guru dalam upaya tersebut dengan 
membudayakan: Menanamkan niat yang baik, budaya menghormati orang tua, budaya menghormati guru atau pendidik, budaya menghormati ilmu, budaya mengasihi sesama, dan budaya menyesal setelah berbuat salah.

Di sinilah konsep Thomas Lickona dan al-Zarnuji peneliti padukan dalam sebuah pembudayaan perilaku baik dalam lingkungan sekolah. Al-Zarnuji dalam cermin besarnya telah memberikan sebuah nuansa tentang pendidikan ideal, sebuah pendidikan yang bermuara pada pembentukan moral. Apabila dianalisa maka akan kelihatan dengan jelas jika al-Zarnuji mengutamakan metode yang bersifat normatif. Metode-metode normatif tersebut kemudian peneliti ejawantahkan dalam sebuah budaya yang harus dibangung dalam lingkungan sekolah. Dalam pembudayaan ini pendidik mempunyai peran sentral dalam mendidik, membimbing dan mengarahkan peserta didik ke arah budaya-budaya Islami.

Membahas tentang pendidikan karakter di sekolah tentu tidak lepas dari pola interaksi antara peserta didik dengan pendidik serta sosialisasi nilai-nilai karakter yang ada. Dengan demikian peserta didik dapat hidup selaras dengan lingkungannya. Peserta didik dengan pola ajar dan teladan yang baik, akan membuat ia merasa disayang, dilindungi, dianggap berharga, begitu juga sebaliknya. Hal tersebut sangat berpengaruh pada proses tumbuh kembangnya kepribadian peserta didik. Fitrahnya anak terlahir bagai lembaran kertas putih. Ia terbentuk, belajar dari meniru orang lain, dan lingkungan yang ada disekelilingnya.

B. Saran

Pada akhir penelitian ini peneliti ingin memberikan saran bahwa pendidikan karakter tidak selesai sampai di sini, kita sadari bersama bahwa menciptakan sebuah karakter tidak semudah memberikan teori bahan ajar terhadap peserta didik. Butuh waktu, proses dan pembiasaan secara berulang. Maka tidak ada kata bosan dan menyerah untuk sebuah perubahan perilaku baik. Kesabaran dan ketelatenan bagi pendidik merupakan modal utama dalam menjalankan tugas mulya ini.

Tentu hal ini tidak saja dilakukan seorang diri oleh guru Pendidikan Agama Islam, sebab pendidikan karakter pada prinsipnya merupakan tanggung jawab kita bersama baik pemerintah, orang tua, pendidik dan tenaga kependidikan.

Sadar dengan kekurangan yang dimiliki oleh peneliti, konsep yang peneliti tawarkan di atas tentu masih butuh pada penyempurnaan yang lebih matang sehingga cita-cita kita bersama dapat terwujud nyata. Untuk itu, segala bentuk kritik dan saran demi sempurnanya sebuah konsep pendidikan karakter tetap peneliti butuhkan. 


\section{DAFTAR PUSTAKA}

Al-Syaibany, Omar Mohammad Al-Toumy. 1079. Filsafat Pendidikan Islam, terj. Hasan Langgulung, Jakarta: Bulan Bintang.

Al-Qardawy, Yusuf. 1980, Pendidikan Islam dan Madrasah Hasan al-Banna. Jakarta: Bulan Bintang.

Al-Zarnuji. Ta'lim Muta allim Tariq al-Ta'allum. Surabaya: Maktabah Hidayah.

Ahmadi, Abu dkk. 1992. Ilmu Pendidikan. Jakarta: Rineka Cipta

Amin, Ahmad. 1995. Etika (Ilmu Akhlak). Terj. oleh Farid Ma'ruf. Jakarta: Bulan Bintang. Cet. VIII.

Amin, Moh. 1992. Pengantar Ilmu Pendidikan Islam. Pasuruan: PT. Garoeda Buana Indah.

An-Nahlawi, Abdurrahman. 1989. Prinsip-Prinsip dan Metode Pendidikan Islam Dalam Keluarga, di Sekolah dan di Masyarakat. Bandung: CV. Diponegoro.

Arifin. Filsafat Pendidikan Islam. Jakarta: Bumi Aksara.

1994. Ilmu Pendidikan Islam. Jakarta: Bumi Aksara.

Asrori, Ma'ruf. 1996. Etika Belajar Bagi Penuntut ILmu, Terjemah Ta'lim alMuta'aliim. Surabaya: al-Miftah.

Athiyatullah, Ahmad. 1970. Qamus Islami. Mesir: Maktabah Nahdlah, Jilid ke-3

Bahreisj, Salim. 1987. Tarjamah Riyadhus Shalihin I. Bandung: Al-Ma’arif.

Bin Nuh, Abd dkk. 1971. Kamus Indonesia-Arab. Jakarta: Mutiara.

Daradjad, Zakiah. 1996. Ilmu Pendidikan Islam. Jakarta: Bumi Aksara.

Dimyati. 2010. Peran Guru sebagai Model dalam Pembelajaran Karakter dan Kebajikan Moral Melalui Pendidikan Jasmani, dalam Cakrawala Pendidikan. Yogyakarta: Edisi Khusus Dies Natalis UNY.

Doni Koesoema A. 2007. Pendidikan Karakter: Strategi Mendidik Anak di Zaman Global. Jakarta: Grasindo.

Faisal, Sanapiah. 1990. Metode Penelitian Kualitatif. Surabaya: Usaha Nasional. 
Frye, Mike at all. (Ed.) (2002). Character Education: Informational Handbook andGuide for Support and Implementation of the Student Citizent Act of 2001. North Carolina: Public Schools of North Carolina

Gunawan, Heri. 2012. Pendidikan Karakter Konsep dan Implementasi. Alfabeta: Bandung.

Ilyas, Asnelly. 1995. Mendambakan Anak Shaleh. Bandung: Al-Bayan.

Imron Arifin. 1996. Penelitian Kualitatif dalam Ilmu-Ilmu Sosial dan Keagamaan (Malang: Kalimashada).

Kamus Bahasa Indonesia/Tim Penyusun Kamus Pusat Bahasa, 2008. Jakarta: Pusat Bahasa, cet. xvi

Kesuma, Dharma dkk. 2012. Pendidikan Karakter Kajian Teori dan Praktik di Sekolah. Bandung: PT. Remaja Rosd ${ }^{\wedge}$ rnam

Lexi J. Moleong. 2002. Metodols

Kualitatif. Bandung: PT Remaja Rosdakarya.

Lickona, Thomas. 2012. Educating for Character: Mendidik untuk Membentuk Karakter. Jakarta: Bumi Aksara.

1991. Educating for Character. New York: Bantam Books.

2004. Character Matters. New York: Somon \& Schuster.

Lorens Bagus.1996. Kamus Filsafat. Jakarta: Gramedia.

Ma'mur Asmani, Jamal. 2011. Buku Panduan Internalisasi Pendidikan Karakter di Sekolah. Jogjakarta: DIVA Press.

Maftuhin. 2009. Pengaruh Arahan Pendidikan Oleh Keluarga dan Kompetensi Guru Terhadap Pembentukan Karakter (Character Building) Siswa SMP Al-Izzah Islamic Boarding School Batu. Tesis. Malang: Universitas Islam Negeri (UIN) Maulana Malik Ibrahim Malang.

Majid, Abdul dkk. 2010. Pedidikan karakter dalam perspektif Islam. Bandung: Insan Cita Utama.

Marimba, Ahmad D. 1989. Filsafat Pendidikan Islam. Bandung: PT. Al-Ma'arif.

Megawangi, Ratna. 2009. Pendidikan Karakter; Solusi Tepat Untuk Membangun Bangsa. Jakarta: Indonesia Heritage Foundation. Cet III.

Muhaimin dkk. 1993. Ilmu Pendidikan Islam. Surabaya: PT karya abadi tama. 
Mulyasa, E. 201. Manajemen Pendidikan Karakter. Bumi Aksara: Jakarta

Musthafa, Ali Yaqub. 1986. "Etika Belajar Menurut Az-Zarnuji," Pesantern, No.3 Vol.III, No. 3.

Nata, Abuddin. 2003. Pemikiran Para Tokoh Pendidikan Islam Seri Kajian Filsafat Pendididikan Islam. Jakarta: Raja Garfindo Persada.

Nur, Unbiyati. 1997. Ilmu Pendidikan Islam 2. Bandung: PT. Pustaka Setia.

Racham, Maman. 2001. Reposisi, Re-Evaluasi dan Redefinisi Pendidikan Nilai bagi Generasi Muda Bangsa, dalam jurnal pendidikan dan Kebudayaan. Jakarta: Balitbang Depdiknas.

Ramli, Teuku Zakaria. 2000. Pendekatan-Pendekatan Pendidikan Nilai dan Implementasi dalam Pendidikan Budi Pekerti, dalam Jurnal Pendidikan dan Kebudayaan. Jakarta: Balit No. 026.

Samani, Muchlas dkk. 2012. Kons 'endidikan Karakter. Bandung: PT. Remaja Rosdakarya.

Surahmad, Winarno.1994. Dasar dan Teknik Penelitian. Bandung: Trasito.

Sutrisno Hadi. 1987. Metode Research I. Yogyakarta: Andi Offset.

Syekh Ibrahim bin Ismail, al-Syarh Ta'lim al-Muta'llim, (Indonesia: Maktabah Daar Ihya' al-Kutub al-'Arabiyah, $\mathrm{tt}$ ).

Wahidmurni. 2008. Menulis Proposal dan Laporan Penelitian Lapangan: Pendekatan Kualitatif dan Kuantitatif (Skripsi, Tesis dan Disertasi), Malang: PPs UIN Malang,

Kristen Yuliarti. 2008. Desan Pembelajaran Untuk Proses Pendidikan Karakter Anak (Studi Fenomenologi pada SD Kanisius Manguan Yogyakarta). Tesis. Malang: Universitas Negeri Malang (UM).

Mudyahardjo, Redja. 2002. Pengantar Pendidikan: Sebuah Study Awal Tentang DasarDasar Pendidikan Pada Umum dan Pendidikan di Indonesia. Jakarta: PT. Raja Grafindo Persada.

Muhaimin, dkk. 1996. Strategi Belajar Mengajar: Penerapan Dalam Pembelajaran Pendidikan Agama. Surabaya: Citra Media.

Noer Aly, Hery. 1999. Ilmu Pendidikan Islam. Jakarta: Logos, 1999.

Qomar, Mujamil. 2003. Meniti Jalan Pendidikan Islam. Yogyakarta: Pustaka Pelajar. 
Tim Penyusun Kamus Pusat Pembinaan dan Pengembangan Bahasa. 1989. Kamus Besar Bahasa Indonesia, Jakarta: Balai Pustaka.

Undang-Undang Republik Indonesia No. 20 tahun 2003 tentang Sistem Pendidikan Nasiona. Bandung: Citra Umbara.

Zubaedi. 2011. Desain Pendidikan Karakter Konsepsi dan Aplikasinya dalam Lembaga Pendidikan. Jakarta: Kencana.

Zuhairini dkk. 2004. Metodologi Pembelajaran Pendidikan Agama Islam. UM Malang bekerja sama dengan Fak. Tarbiyah UIN Malang. 